\title{
Justyna Straczuk*
}

\author{
RISK AND TRUST. \\ FOOD-RELATED CONCERNS \\ AND 'GOOD' FOOD PROCUREMENT STRATEGIES. \\ FROM RESEARCH INTO EATING PRACTICES IN POLAND' ${ }^{1}$
}

\begin{abstract}
The article discusses how risk and trust - interpreted as social phenomena characteristic of the late modernity era - are reflected in the concerns related to everyday food choices of residents of Poland. It postulates a link between the perception of food-related threats and the meanings associated with different food procurement practices, and the specifics of a local value system and its historical determinants. Based on the analysis of responses from 70 interviewees speaking about food-related concerns, it outlines diverse strategies for verifying food choices and the types of trust that are granted to various social actors who take part in the production and distribution of food. Since the strategies and forms of trust are largely associated with social and cultural assets of consumers, the article also brings into focus their stratifying aspect, as well as levels of overall trust in people, institutions and abstract systems.
\end{abstract}

Keywords: trust, risk, social concern, food, daily practice, shopping

Theorists of modernity have long since identified the sense of danger and risk as a new, historically-determined form of uncertainty, one of important modern socio-cultural phenomena. Although threat and insecurity have accompanied humans since the dawn of time, their modern manifestations are of a unique kind. Niklas Luhmann (1988) elaborates on a notable difference between danger in the past and risk in the present, by associating it with the transition from cosmological to technological order. In the pre-modern era danger was perceived as a matter of fate, a direct result of natural or divine forces that rendered man powerless, and were beyond human agency. The only antidote was trust in auspicious fortune or divine providence. According to Luhmann, danger is a threat of potential loss in the future that comes from outside, regardless of an individual's actions. The risk that was introduced with the modern era and replaced the traditional concept of danger is linked directly to human

* Corresponding author: Justyna Straczuk, Polska Akademia Nauk, Instytut Filozofii i Socjologii, e-mail: justyna. straczuk@ifispan.waw.pl.

1 This article is part of the project "Eating patterns, lifestyles and social stratification in comparative perspective" conducted at the Institute of Philosophy and Sociology Polish Academy of Sciences with funding from the National Science Centre, Poland (grant number UMO-2011/03/B/HS6/03983). 
responsibility, both in its generation and management, and is a consequence of an individual's actions and decisions. It is a threat of loss resulting from making good or bad decisions, which makes it subject to moral judgments (Luhmann 1993).

In the writings of Ulrich Beck $(1992,1998)$ risk emerges as a key category for describing the society of late modernity. Beck associates risk with universal social processes such as globalisation, individualisation and reflexivity. The global and unlocalized nature of risk makes it a common experience relevant to everybody, not easy to manage and difficult to avoid. It is also often elusive and difficult to comprehend, and it brings about gradual and potentially long-lasting negative effects. Beck also brings into focus the growing individualisation and privatisation of risk that is perceived as lending itself to management and involves individual choices, responsibility, and guilt. This increased risk awareness is also fuelled by institutional and individual reflexivity as well as a perceived random and fleeting aspect of expert knowledge that is continuously revised and altered, causing us to doubt its progressiveness and reliability. Anthony Giddens $(1990,1994)$ writes in a similar tone about 'manufactured uncertainty' as a fundamental aspect of late modernity, linked to the questioning of traditional order and the production of diverse systems of knowledge, in which science has lost its dominant position. The more knowledge, the higher the uncertainty, which in turn fuels the sense of confusion, inability find one's place in the world, lack of trust in social institutions and authorities, and a growing sense of threat present in everyday life, a threat that each individual needs to handle on their own.

A somewhat different view on the topic of risk is adopted by Mary Douglas (1992), who applies a functional approach to its analysis. Her definition of risk places it in a broader context of social groups maintaining boundaries and defences against strangeness, deviation and anomalies that pose a threat to the group's integrity. In this light, risk becomes a cultural response to breaking the rules, which leads to undermining social values and expectations. It is a specific political strategy for coping with danger and strangeness. It is also used to legitimize the moral order. Douglas emphasizes that the understanding of risk is culturally relative. What is perceived and conceptualized as risk depends on the historical and cultural context. Social perception of risk is always mediated by cultural processes and shared conventions and expectations, rather than individual judgement. Questions arise as to why some dangers are identified as risks while others are not, how 'real risk' becomes more important than other kinds, and how it is used in social relations, how it becomes political, an instrument for stigmatizing, marginalizing and assigning blame.

While Douglas focuses on guilt as a moral dimension of risk, others, in particular Luhmann and Giddens, approach risk and related concepts in reference to trust. Both authors demonstrate that the nature of modern threats and risk as well as their intensified perception has also generated changes in the mechanisms of social trust. In traditional societies trust was predominantly habitual and automatic because people usually lived in a familiar environment that would not undergo rapid changes. The main sources of threat were nature (unpredictable weather, natural disasters, contagious diseases), other people (wars, assaults, etc.), evil magic, and the loss of divine grace. In this context, trust was predominantly directed at the local environment: the local community, the kinship group, and the system of religious beliefs and traditions. In the modern era, the sense of threat and insecurity is largely rooted 
in reflexivity and the increased perception of risk related to it. Stability is based on trusting abstract systems, impersonal rules, and faceless others. Consequently, trusting had to become more active since people increasingly engaged in long-distance relationships, which requires repeated authentication of trust that is no longer rooted in everyday experience and instead requires proactive maintenance by both sides. Applying his distinction between danger and risk, Luhmann claims that in the pre-modern era the response to danger was 'confidence' in divine providence or fortune, which allowed people to maintain a sense of relative security. Confidence did not require any activity on the part of the individual, who instead trusted external factors and held them responsible for any misfortunes. Meanwhile, engagement and risk are implicit in trust, since the effects of an individual's efforts might bring disappointment directed at their own bad decisions and actions.

While theorists approach the problem on a macro scale, a question remains how the perception of threat and risk factors into everyday practice. The main focus of this article is the analysis of concerns related to the most rudimentary everyday activity: eating. Risk and trust are categories especially frequently called upon in relation to food. This is largely due to the overall increase of public awareness of food production processes, its chemical components and potential undesired effects of its consumption, 'awareness-raising' campaigns about food-related threats, and media panic waves around diseases caused by consuming meat from livestock that has not been properly handled, 'artificial' GMO foods, and publicized food fraud scandals. All of the above factors fuel the sense of lack of control over what we eat, and a lack of trust in profit-oriented economic systems and agents in the food distribution chain that sell food, whose journey from the field to the consumer's plate is far too long.

The sense of threat is by far more elusive now than it was in the past, when people also experienced fears largely related to lack of food, its low quality, or food poisoning resulting from bad hygiene. Modern food impurity is of a different order, however, that of 'contamination'. Its complex chemical formulae render human senses unable to provide the entrypoint protection they used to offer by detecting the smell, taste and texture, which gave the consumer at least some sense of control. In the past, even in the case of formerly widespread types of food poisoning, for example caused by salmonella, the situation was fairly clear and the culprit easy to identify. Currently, the main problem area is unreliable information: with the media cautioning the public also against products that until recently were viewed as healthy, with experts contradicting one another and thus adding to the sense confusion and distrust towards information sources that used to be perceived as reliable. In the end, individuals are left to their own devices while deciding which information is important and which is not, or whether it should be taken into account or disregarded in favour of one's own intuitions.

What factors are important in identifying and assessing food-related risk and what, if any, are the coping techniques? Are food-related concerns equally important to everybody and do they refer to the same threats? What strategies are employed to ensure a relative sense of security in relation to food? How is trust built and is it placed in people or institutions?

My analysis is based on the qualitative component of the Wzory jedzenia a struktura społeczna (Eating Patterns and Social Structure) research project (Domański et al. 2015). The qualitative study consisted of 70 free-form interviews with respondents living in different regions of Poland, representing a variety of social and demographic characteristics 
corresponding to the national sample that was the basis for questionnaire interviews. The interviews, conducted throughout 2014, lasted one to four hours and touched on a variety of aspects of everyday eating practices (organization and content of meals, shopping, receiving guests and paying visits, eating out, distribution of household chores, the art of cooking, etc.), preferences and attitudes (favourite dishes, attitude to healthy diet, perceived changes in eating behaviours, etc.) and opinions (on Polish, traditional, local, healthy, etc. cuisine). The problem of food-related threats and concerns was not organized into in one section, nor were the respondents prompted to talk about it, and questions about food-related risks and levels of trust were not asked directly. However, while talking about healthy food, changes in eating habits and shopping routines, food-related concerns emerged spontaneously in the narratives with a frequency and intensity that warranted a separate discussion of the topic.

The key word that dominates in the context of food-related concerns is 'chemicals' perceived as the opposite to anything that is viewed as 'natural' food, food that is proper, good and harmless. As one of the informants states: 'Good food is simple food, without any chemicals in it. It is natural, made by earth and animals' The core meaning of the term 'chemicals' encompasses everything that is added to food to optimize the production process: fertilizers, artificial animal fodder, aromas, preservatives and other substances that are usually listed as chemical symbols on the labels. 'Chemicals' are bad for the health, cause diseases and represent a direct threat to a person's well-being.

It's practically only chemicals nowadays. Don't even mention it. Anything you take from a shelf contains the Es. E this, E that, E something or other". [49]

One in two or, say, three people eats a kilogram of chemicals, a kilogram each year, of chemicals you don't even see, in products such as flavour granules or other stuff of this kind, all those enhancers, improvers, dyes and so on. [54]

In a much broader sense, 'chemicals' is a term associated with the mixing of two orders: 'natural' and artificial, contaminated, polluted. As such, it represents a disturbance in the 'normal' state of things and, as described by Mary Douglas (1992), entails ethical valuation. 'Chemicals' become a metonymy for the decayed, polluted world and its continuously deteriorating state of health and morals. The world contaminated with chemicals is often juxtaposed with the idyllic primal state - natural, uncomplicated, genuine and just.

[In the past] people were healthy. Now they are not. So tell me, what do we eat now? What do we eat? Nothing. Everything's sprayed with chemicals. A housewife would grow her own cucumbers, squash, all your veggies were home-grown. [44]

The vision of the world's progressing deterioration ('Well, you know, there used not to be so much of the chemicals, but now it's a tragedy, I mean, really.') reaches apocalyptic dimensions with the images of ecological catastrophes, barren fields and forests and aberrant food-processing practices that only prove their 'abnormal', suspicious character.

There are no blueberries or raspberries now. There's nothing really. It's hard to find a mushroom. There used to be so many blueberries, strawberries. I've been so many times to the same places where they used to grow and it's all gone. [49] 
Risk and trust. Food-related concerns and 'good' food procurement strategies...

These potatoes are inedible. Luckily, we've got the Cyprus potatoes. I buy the Cypriot ones. Only one kilo but at least they're decent to eat. These [...] these, sadly, just turn black, when you cook them. There's so many chemicals in them. [11]

This state of affairs is blamed on the abstract system that conceals the production processes from consumers, on bloodthirsty capitalism, on foreign corporations, and on a lack of state control. The system change that brought about this situation is viewed in a negative light and the world is seen as spinning out of control, with changes going in the wrong direction and impossible for anybody to control.

- Would you say food used to be better in the past?

- Yes, no comparison. Way better, it's a disaster now, now everything is ..

- When did it all change? 20 years ago or earlier than that?

- I guess that's when it happened. Even in the communist times it was better. It really was. There was some supervision. There's no control now. All they do is fight, nobody knows why and what for. [11]

There are also accounts of dishonest actions by specific groups - manufacturers and, notably intermediaries in the food distribution channels - that add to the picture of moral decline. The world's decaying state is manifested and takes the form of unethical dealings of specific individuals who break fundamental rules and of dishonest behaviours that the respondents often only witness and at times adopt, through inertia and without moral qualms.

Although nowadays the same producers have their own meat processing plants, and they pump it full of water, too. There's not much difference from the supermarket food, well, except you may know more about where the meat comes from, than that sold in supermarkets. But, generally speaking, they also pump as much water as they can into the meat, and some other stuff, to make sure every bit is used, that nothing gets wasted. And there's this 'refreshing' of old cured meats, or grinding them and turning them into sausage. [49]

All such accounts are accompanied by a sense of limited control or complete lack thereof, not being able to decide about the quality of food consumed, instead being doomed to consume 'chemicals', which all emerges as a kind of fate as described by Ulrich Beck: 'Now there exists a kind of risk fate in developed civilization, into which one is born, which one cannot escape with any amount of achievement' (Beck 1992: 41). Fate refers not only to the unavoidability of consuming contaminated food, but also to living in a contaminated environment, one in which the earth is no longer able to produce food without artificial enhancement. Hence, numerous opinions rationalize and justify the use of chemical fertilizers or spraying plants with chemicals, without which farmers would not be able to support themselves from the fruit of their work.

First of all, now farmers have to spray pesticides or all their produce will get spoiled. Bugs will eat it all up, so they just have to spray it, because it's all so contaminated, I mean the soil is, that it won't work. The only thing that is important is the date. I mean when you're told that food can be sold two days after being sprayed with chemicals. [24] 
Only now it's not really possible, is it? They have to stuff it with chemicals, because there are all these $[\ldots]$ germs or bacteria. Or whatever attacks plants, all such things. And they have to spray it. [...] And as I said, because it's used on a mass scale, to get enough of a good product, make them grow large, healthy and look good. It's not possible without chemicals. [49]

Consuming 'chemical' food emerges as an inevitability in the world where 'nothing else is possible'.

What do we eat then? Chemicals. Nothing else. But then, what else is there to eat? [6]

But this is the world we live in. $90 \%$ of people have to eat what is available. You have to eat something anyway. So far we haven't invented a pill that could cure hunger. [26]

However, there is a broad spectrum of responses to this reality, from radical pessimism and ignorance along with abandoning any attempts to take preventive measures, through moderate optimism and a belief that it is possible to mitigate the risks, which however requires personal commitment. We will examine these different strategies. How do individuals go about making their food choices, where do these choices come from and what is the rationale behind them? Is there any food that can be trusted, and if so, what are the determinants and dimensions of that trust?

\section{TRUST STRATEGIES}

Food-related concerns and fears reflect the processes of growing uncertainty and lack of control typical of the societies of late modernity as described by theorists. In such circumstances trust gains particularly high importance, becoming a resource necessary for building a sense of relative stability and security. In this context Giddens points to the modern transformed 'environment of trust'. In traditional societies trust (or perhaps we should use Luhmann's term confidence) was placed mostly in the relations of kinship, with the local community, in religious cosmogonies and tradition. In the modern era there is a growing prevalence of trust in relations other than kinship, trust in a growing number of relations with anonymous strangers and with abstract systems. There are also more faceless obligations, i.e. involving trust rooted in the belief in the symbolic rather than personal obligations sustained through social bonds formed through co-existence.

For a number of years social trust has been a prominent theme of sociological thought in Poland. Described as 'the foundation of society' (Sztompka 1999), believed to be a crucial component of cultural and social capital, a ground for social bonds and a requisite for a functional civil society and democracy, social trust has been a constant object of sociologists' concern, as for years research has repeatedly shown that when compared to the residents of other European states Poles manifest a very low degree of social trust (Sztabiński and Sztabiński 2014), in particular with respect to public institutions. Henryk Domański explains this by the express transition from authoritarian rule and planned economy to democracy (Domański 2014: 23). Piotr Sztompka (1999) also calls upon macro-structural factors such as radical social change, a lack of normative cohesion, and organizational transparency as 
potential drivers of low social trust. Domański claims as well that low trust in public institutions causes individuals to maintain strong personal bonds with family and friends. In fact, a case could be made for the reverse: strong personal bonds contributing to the low institutional trust in Poland. Indeed, the results of nation-wide surveys conducted by Poland's Centre for Public Opinion Research (CBOS) as well as the Main Statistical Office (GUS) indicate that the residents of Poland are the most likely to trust people in their immediate environment: family (98\% of the respondents), and acquaintances and friends (93\%). The lowest share of respondents declared trusting strangers (39\%) (GUS: 2015). Nearly identical statistics emerged from a study conducted by CBOS: $98 \%$ of the respondents declared trusting their family, including $81 \%$ of unmitigated 'trust completely' responses. Acquaintances and friends are trusted or 'somewhat trusted' by $92 \%$ in total, while relatives by $88 \%$ and strangers only by $32 \%$ (CBOS: 2016).

According to most researchers, such trust patterns are quite typical for the societies of former communist states. Charles Tilly (2005) writes that networks of trust actually form historically diversified types of relations with various forms of socio-political organization. Strongly personalised and exclusive social networks, often pejoratively labelled as 'dirty communities' (Podgórecki 1976), or 'amoral familism' (Tarkowski and Tarkowska 1990) due to their propensity for social exclusion and particularism, are presented as a ramification of the division between the private and public spheres produced by the former political system. In communist times, low social trust in the ruling class was compensated for by intensified participation in familial communities and closed family circles. Informal networks and familial bonds also formed the foundation of everyday lives, as the so-called 'contacts' and systems of access to rationed consumer goods allowed people to survive years of economic crisis and supply shortages.

In the studies of Piotr Sztompka (1999) trust was closely related to the individual's socio-demographic characteristics: level of education, performed social roles, and strong family bonds (the last among individuals without high socio-economic status). The question of whether they feel they are trusted was answered in the affirmative by $19 \%$ of low-income and $45 \%$ of high-income respondents, $20.7 \%$ of uneducated vs. $25.4 \%$ of educated Poles, $17.5 \%$ of unemployed individuals, and $36.6 \%$ of professionals. Sztompka also claims that on the individual level, people with high self-esteem and a strong sense of individuality are more likely to trust people in general (including strangers) as well as institutions and systems (formal institutions and abstract systems).

The above pattern that emerges from national surveys is also reflected in attitudes and everyday practices related to selecting and purchasing food. In the face of the general sense of threat by contaminated food and the dangers it poses to health, the choice of good and trustworthy products that might to some extent mitigate food-related concerns and fears requires taking measures to find acceptably reliable sources of food and information about it. What are the levels of trust towards various sources of food supplies? What strategies are adopted when choosing and purchasing food, to ensure relative security and psychological comfort?

A considerably large group of respondents, predominantly of lower social status, declared not trusting anybody but themselves. Only participation in the food production process or direct observation thereof gives one the assurance that the food is indeed good and healthy. 
Consequently, only the food produced by themselves or people from their closest circle can be fully trusted.

Only I don't really trust it. I mean I only do, when I make it myself, when I grow it myself. Then I can say that it is mine, the way it should be. [6]

Really healthy, the way I see it is, if I grew it myself, sowed, planted, weeded, harvested, fed, butchered, cooked - right? Then I would know for sure that it is healthy. [36]

In this context emerges a category of 'familiar' [swoje $]^{2}$ food, which designates food that, if not made in the respondent's household, comes directly from a farmer who produces it only for their own use or for the use of their family, closest friends, and relatives. It is a critical category that frequently appears in the food narrative in contrast to commercially-produced food, manufactured for sale, with profit as the main consideration, far above quality and health value. 'Familiar' food relates directly to the sense of community, belonging, familial bonds, and kinship, where trust is habitual, automatic, and only the best intentions are assumed. 'Familiar' food is therefore a synonym of good food, food 'as it should be': its highest quality is taken for granted, no need for verification. It is food that is undoubtedly 'genuine'. It offers complete safety and resides at the top of the trust scale.

Good food? I'd say home-made. Not the food you buy from a supermarket, in cling film packets. It has to be from trusted sources. You need to know where, what and from whom you are buying it, how it has been grown and all that. The best is when it's home-produced, like on a country farm. You know what you feed to animals and what we are going to eat later. [10]

Meat, it's best if you don't buy it from a distributor but go to a farm, buy a piece from somebody you know and prepare it yourself. Then it's healthy and at least I know that there are no chemicals in it. [57]

Inherent in the concept of food 'familiarity' is a specific kind of longing for an idyllic country pastoral, a return to life in harmony with nature and social values, the times of farmstead self-sufficiency and local communitarianism. With such connotations, familiar food is perceived as thoroughly natural, a source of unique sensual experience through 'genuine' smell and, above all, taste. The 'familiar' taste is a distinctive feature of good food as well as a form of cultural code, a manifestation of a bond with nature and community. 'Familiar' is the food that is not only natural but also morally pure.

Meat. That's where real meat is, no chemicals involved. I can imagine what they can do with meats with large processing plants, all those food factories. On the other hand, I can see what my brother-in-law does with meat. I like the look and the taste of it. The smell is right, the taste, the colour, everything is just right. [35]

The sense of taste is an individual's most reliable instrument for identifying good food. While the look, touch and smell can be helpful in the first contact with the product, particularly

2 It is hard to translate this term into English since aside from 'familiar' it connotes 'home-made/home-grown', 'our own', 'native'. 
Risk and trust. Food-related concerns and 'good' food procurement strategies...

during shopping for fruit, vegetables or meat, they fail to provide complete control over the quality of purchased food. Eyes focus on the external appearance and are easily deceived by the semblance of good food. Meanwhile taste, which comes in contact with the physical substance of the product, is by far a more reliable sense. Taste and how it is experienced appears to be a more internal, deeper, 'core' attribute of an individual, closer to natural instincts. Distinguishing natural from artificial is thus the domain of the body, its most "biological" sense - taste, that seems to belong entirely to the realm of nature.

You can. The difference is huge. Traditionally smoked meats, everybody can tell the difference. It's like two completely different types of meat. You'd know right away what was traditionally smoked. It's a completely different taste, different from typical chemically-treated stuff. Let me put it this way, sometimes I go to weddings and other events where they serve food to guests. Often meats are carefully arranged on trays for the guests to help themselves. So you taste a piece here and a slice there and in the end it turns out that, even though they are different products, they all taste the same. That's strange. Once I was at a wedding feast and I saw this ham, it looked like boiled ham, something of the kind, in slices. It tasted like fish, it had this funny aftertaste but it was meat, at least it looked like meat, not fish meat, but that taste. [26]

The system of procuring 'familiar' food directly from a farmer was particularly welldeveloped in communist times, as an efficient way to gain access to foods that were rationed in the times of economic shortages (Kochanowski 2010). It was also a consequence of the rural ancestry of the majority of Poles who continued to have strong bonds with the countryside. This style of procuring food has remained singularly durable and a vast majority of the respondents admitted to maintaining active channels for procuring 'country' products, either through family or neighbourhood connections or growing their own fruit or vegetables, through contacts made in the countryside during summer vacation or friends who bring such products to the city. Recently, there has been a growing movement of more or less formalized alternative food-provision communities that bring farmers and city-dwellers together (Bilewicz and Śpiewak 2015). Nevertheless, the scale of such undertakings is still marginal and they are popular mostly among the younger members of the urban middle class.

Products of the 'familiar' order, brought directly from a farmer, personally or by friends, by no means satisfy all needs of city dwellers who are left to buy food that is not granted trust as automatically and habitually as 'familiar' food would be. The mechanism of active trust, which requires consumers to verify the intermediaries, labels and certificates that are a part of the abstract systems domain, is initiated only at the moment of purchasing commerciallyproduced food that fails to provide a sense of security related to knowing how it was made.

At the beginning the second millennium, at the dawn of the supermarket chain offensive in Poland with Polish consumers happily embracing this consumer model, Roch Sulima (2000) made an interesting comparison between this 'modern' commercial practice and the traditional world of marketplaces. A marketplace is an arena of culturally grounded forms of exchange, face-to-face contacts, where the seller's narrative gives the product an individual history and credibility. Meanwhile a supermarket is a thoroughly modern and anonymous setting that does not allow for developing new bonds, a place where no human interaction is involved in handling products, with labels as the only source of formalized product information, legitimized by impersonal knowledge rather than human-to-human contact. 
Knowledge about products falls into the category of 'thin familiarity' (Giddens 1990). While consumers do not have access to the producer nor the opportunity to observe the production process, they engage in hand-to-hand exchange involving a degree of trust that obliges the other party to fair treatment. In the axiological sense, the experience is similar to an exchange of gifts, with both parties expecting ethical treatment. In this model of human interaction, information asymmetry between the seller and buyer is somewhat lesser than in the mass commerce context because, by trusting the seller, the buyer invites them to return the favour.

Everybody needs to take care of their own needs. I mean sometimes you really need to put in some effort to buy healthy food. Sure, you're told to read labels [...] but when you're shopping in a marketplace you trust the seller not the label - the seller is the brand [...] These are people you know. Those you buy from greet you before you come up to them 'Good morning'. People know one another, know where you came from.

Never, even if there were something, I'm convinced that that person wouldn't unload it on me, make me buy it, because they know that I come back every Wednesday. [44]

The marketplace is predominantly a place to shop for fresh fruit and vegetables, less so for raw or cured meats. Consumers mostly look for food grown by the seller - products from a small output farm that produces food for its own needs, directly from a farmer, a small producer, a trusted 'eco' source. Becoming acquainted with the seller plays a crucial role in building trust in the product's right provenance, striking up a conversation, acquiring a verbal testimony. No further verification is required and the seller's word is usually accepted. Habit is also an important factor, returning to the same 'well tried' suppliers who have already earned the consumer's trust and who have not failed them so far. Sometimes a consumer follows a recommendation from a trusted source, which is particularly important in the first contact.

I trust her. I've been buying from her for years and nobody ever complained about anything. I am convinced she has a good supplier. [50]

I have my trusted sellers and I think they have better and natural products, like apples they grow for their own use. They have a small number of apple trees and they don't treat them with pesticides so much. At least that's as far as I know, or they try to give their chickens food without corn. [37]

Non-verbal forms of verification of a product's 'familiarity' include also assessing the seller's appearance ('the farmer look'), a limited choice of products that seems to confirm that they are selling only their own produce, modest appearance of fruits and vegetables suggesting that they have not been treated with chemical fertilizers or pesticides, and often traces of soil on the products, as though brought straight from a field. A moderate price is another indicator, suggesting that it does not include an intermediary's profit.

And I buy my carrots at a marketplace, straight from a farmer. There is this woman I know who sells whatever she's not able to use herself. You never know how much she'll have, and it's only from time to time, that makes me sure that [...] I know that what she sells must be grown by her. 
Now, in a shop, let's not kid ourselves, there are chemical fertilizers, all the other stuff. Practically only chemicals. [6]

Take tomatoes, for example. In summer they sell tomatoes that grow in a field. You buy it for pennies and it really tastes like a tomato, and if you buy the beautiful ones, arranged in crates, eight zlotys per kilo, there's practically no tomato taste. [45]

Direct observation is another strategy for verifying the source of products and their quality. A stand's or shop's popularity is interpreted as a sign that it sells fresh and tasty products (tested and approved by multiple consumers). As well, witnessing part of the process is important as a substitute for controlling the production process, for example watching a butcher cut up meat on the spot,

Cured meats from Szubert's. I know the products are fresh because they sell out. When you get there in the morning you see them always bringing new meats. [10]

In the Okraqglak market hall. There's this seller there, only on Fridays. He also has a shop somewhere in Huta. He brings meat and cuts it up, cuts off the shoulder, neck... - that's what I mean. [6]

The 'dependable' methods of verification are rarely questioned.

Don't trust them. Came from the country, so what? Most of them are intermediaries. How can I tell how long they have kept the eggs before bringing them. They will tell you the eggs are from this morning but they could have been stored for three or four days. There's truth and there's truth. [4]

Consumers usually question the credibility of faceless, mass-scale forms of commerce. Their anonymity and lack of any insight into the production processes, by definition, does not encourage trust. Interestingly, information and certifications on the package are distrusted as well.

- Do you check the labels when you're shopping? - But is it true? [46]

You know, like there are these shops now that sell 'eco' food. Do you think I trust that? I can't be sure if it is [...]. They said on TV about all stuff that was supposed to be 'eco' and it turns out it is not. [6]

Studying labels is not a common practice in Poland, especially among less-educated individuals. Most consumers check the expiry date, considering it the only important piece of information:

Expiry date for sure, source not so much, because most of the meat that is sold in supermarkets isn't familiar, so there are chemicals in it, so it doesn't really matter what chemicals I'm going to eat. I guess I don't really look at anything else, only the expiry date, to make sure it's not past it. [57]

However, even the individuals who read product information doubt its truthfulness or consider perusing the list of ingredients on the product pointless. Some prefer to remain ignorant as they assume it is impossible to avoid buying unhealthy food. 
All in all, at the moment, if you take any food that is available, it's all full of Es. Sometimes you don't even want to read it all. I don't, don't read any of it, or I wouldn't be able to buy anything. I mean, sometimes when you read the ingredients list, even on a product that's supposed to be super high quality, you read and see how much chemicals it contains, you can't shake it off, but it doesn't bother you if you don't read it. [26]

The few conscious consumers who diligently inspect the labels, usually members of the educated group, stress their competences and their belief in the power of knowledge grounded in science, factors they believe help them to make rational choices.

Now we get a lot of help from A. [daughter who studies food technology], who knows how to explain the label. I mean, E doesn't mean it's not healthy. There are good Es and bad Es. Sometimes it's just a chemical symbol of a natural substance that isn't harmful and sometimes it is a harmful one. So whenever we have doubts, she tells us what the product contains and next time we can decide for ourselves if we want to buy it or not. [17]

Poland does not have high levels of trust in abstract systems represented by the European Union food safety regulations, nor confidence in formalized procedures and institutional control. To some degree this correlates with the results of the national research into institutional trust. In our small sample, anonymous, procedural trust was manifested predominantly among the respondents with higher education, which is also reflected in the national survey (Domański 2016). However, it would be difficult to substantiate the claim that the varying levels of trust significantly affect food-buying practices. The demographic makeup of supermarket and marketplace customer groups is roughly similar. Certainly, there are differences that are mainly due to the more exclusive character of some locations and different prices that are its consequence. However, it is safe to conclude that food-related choices are far more often based on personal trust and obligations than trust in systems and faceless obligations.

\section{CONCLUSIONS}

Food-related feelings of threat and risk are of a unique nature since they refer to bodily integrity, a direct threat to an individual's health. These concerns are further intensified by the inability to rely on valid knowledge on proper nutrition, caused by contradicting information from different representatives of sciences. The mass media and food-related panic waves they initiate are not without importance either. All these factors contribute to the general sense of confusion, a lack of control and agency needed to make good food choices. This leads to perceiving chemical contamination of food as an unavoidable fate, impossible to control.

Socio-economic processes that followed the system change in Poland, transformation of the food market mechanisms, progressing globalisation, increased internal and cross-border migration and social mobility have intensified processes in which people are uprooted from their communities, taken out of the local and familiar environment. As a result, consumers need to develop new forms of trust that are not based directly on context, but on higher 
confidence in impersonal rules and remote relationships not based on direct contact. All this is clearly visible in the sphere of everyday eating habits. As Norbert Elias (1994) has long since observed, in such small, seemingly insignificant practices, major social processes are best reflected.

Eating, which is particularly close to the home and family domain and relies on the most intimate cultural codes, manifests itself in a persistence of traditional forms, and a preference for and placing of the ultimate trust in 'familiar' food, procured outside the commercial mainstream, grown by the consumer, their relatives or friends or brought directly from the countryside, from the farmer who grew it. Another form that bears a semblance of these familiar food-exchange practices is shopping for food in a marketplace, where trust in a product is based on interpersonal relations between the buyer and the seller. High degrees of trust in people in an individual's closest circle, in particular family and friends, continues to stand in contrast with low rates of abstract and institutional trust. This is also evident in the food choice strategies and evaluating its sources and information about it.

$$
\begin{aligned}
& \text { Respondents data: } \\
& {[4]-\text { ME-M-65-S }} \\
& {[6]-\text { ME-K-45-Z }} \\
& {[10]-\text { W-K-45-Z }} \\
& {[11]-\text { ME-K-99-S }} \\
& {[17]-\text { ME-K-45-W }} \\
& {[26]-\text { W-M-45-Z }} \\
& {[35]-\text { W-K-45-S }} \\
& {[36]-\text { W-K-45-S }} \\
& {[37]-\text { W-K-45-W }} \\
& {[44]-\text { W-K-99-P }} \\
& {[45]-\text { W-KM-99-P }} \\
& {[46]-\text { W-K-99-S }} \\
& {[49]-\text { MM-K-65-W }} \\
& {[50]-\text { ME-K-99-S }} \\
& {[54]-\text { DM-M-45-W }} \\
& {[57]-\text { DM-M-45-W }}
\end{aligned}
$$

\section{Description of symbols:}

Place of residence:

ME - metropolis over 500000 inhabitants

DM - big city up to 500000 inhabitants

MM - small city up to 20000 inhabitants

$\mathrm{W}$ - village

Sex:

$\mathrm{K}$ - feminine

$\mathrm{M}$ - masculine 
Age:

25 - up to 25 years

45 - up to 45 years

65 - up to 65 years

99 - over 65 years

Education:

$\mathrm{P}$ - elementary

$\mathrm{Z}$ - vocational

$\mathrm{S}$ - secondary

W - higher

\section{REFERENCES}

Beck, Ulrich. 1992. Risk society: Towards a new modernity, London: Sage.

Beck, Ulrich. 1998. World Risk Society, Cambridge: Polity Press.

Beck, Ulrich, Anthony Giddens and Scott Lash. 1994. Reflexive Modernization: Politics, Tradition and Aesthetics in the Modern Social Order, Stanford: Stanford University Press.

Bilewicz, Aleksandra and Ruta Śpiewak. 2015. Enclaves of Activism and Taste. Polish consumer cooperatives as alternative food networks, "Socio.hu, Special Issue in English: The Social Meaning of Food", 3: 147-166.

CBOS. 2016. Zaufanie społeczne. Komunikat z badań nr 18/2016, Warszawa: Centrum Badania Opinii Społecznej.

Domański, Henryk, Zbigniew Karpiński, Dariusz Przybysz and Justyna Straczuk. 2015. Wzory jedzenia a struktura społeczna, Warszawa: Wydawnictwo Naukowe Scholar.

Domański, Henryk. 2014. Zaufanie do instytucji, in: Paweł Sztabiński and Franciszek Sztabiński (ed.), Polska - Europa. Wyniki Europejskiego Sondażu Społecznego 2002-2012, Warszawa: Wydawnictwo IFiS PAN, pp. 8-18.

Douglas, Mary. 1966. Purity and danger: An analysis of concepts of pollution and taboo, London: Routledge.

Douglas, Mary. 1992. Risk and Blame: Essays in Cultural Theory, London: Routledge.

Elias, Norbert. 1939/1994. The Civilizing Process, Oxford: Blackwell.

Giddens, Anthony. 1990. The Consequences of Modernity, Cambridge: Polity Press.

Giddens, Anthony. 1991. Modernity and self-identity: Self and society in the late modern age, Stanford: Stanford University Press.

Giddens, Anthony. 1994. Living in a post-traditional society, in: Ulrich Beck, Anthony Giddens and Scott Lash, Reflexive Modernization: Politics, Tradition and Aesthetics in the Modern Social Order, Stanford: Stanford University Press, pp. 56-109.

GUS. 2105. Wartości i zaufanie społeczne w Polsce w 2015 r., Warszawa: Główny Urząd Statystyczny, https://stat.gov.pl/.../gfx/.../wartosci_i_zaufanie_spoleczne_w_polsce_w_ 2015r_.pdf [04.12.2017].

Kjærnes, Unni, Mark Harvey and Allan Warde. 2007. Trust in food: A comparative and institutional analysis, Springer. 
Kochanowski, Jerzy. 2010. Tylnymi drzwiami. Czarny rynek w Polsce 1944-1989, Warszawa: GW Foksal.

Kopczyńska, Ewa. 2015. Co to jest jedzenie naturalne? Socjonatura na targowisku, „Studia Socjologiczne", 4: 181-203.

Lash, Scott. 1993. Reflexive Modernization: Politics, Tradition and Aesthetics in the Modern Social Order, Cambridge: Polity Press, pp. 56-109.

Luhmann, Niklas. 1988. Familiarity, Confidence, Trust: Problems and Alternatives, in: Diego Gambetta (ed.), Trust: Making and Breaking Cooperative Relations, Oxford: Blackwell. Luhmann, Niklas. 1993. Risk: A Sociological Theory, Berlin - New York: Walter de Gruyter. Lupton, Deborah. 1999. Risk, London: Routledge.

Podgórecki, Adam. 1976. Kontrola społeczna trzeciego stopnia, in: Problemy profilaktyki spotecznej i resocjalizacji, Warszawa: Wydawnictwa Uniwersytetu Warszawskiego, pp. 24-25.

Sulima, Roch. 2000. Antropologia codzienności, Kraków: Wydawnictwo Uniwersytetu Jagiellońskiego.

Straczuk, Justyna. 2016. Smak trwania, smak zmiany. Preferencje i praktyki jedzeniowe Polaków w kontekście zmiany społecznej, „Studia Socjologiczne”, 3: 31-50.

Sztabiński, Paweł and Franciszek Sztabiński (ed.). 2014. Polska - Europa. Wyniki Europejskiego Sondazu Społecznego 2002-2012, Warszawa: Wydawnictwo Instytutu Filozofii i Socjologii PAN.

Sztompka, Piotr. 1999. Trust: A sociological theory, Cambridge: Cambridge University Press. Tarkowska, Elżbieta and Jacek Tarkowski. 1990. „Amoralny familizm”, czyli o dezintegracji społecznej w Polsce lat osiemdziesiatych, in: Edmund Wnuk-Lipiński (ed.), Grupy $i$ więzi społeczne $w$ systemie monocentrycznym, Warszawa: Wydawnictwo IFiS PAN, pp. 37-69.

Tilly, Charles. 2005. Identity, Boundaries and Social Ties, Boulder and London: Paradigm Publisher.

\section{RYZYKO I ZAUFANIE. JEDZENIOWE NIEPOKOJE I STRATEGIE ZAOPATRYWANIA SIE} W „DOBRĄ” ŻYWNOŚĆ. Z BADAŃ NAD WZORAMI JEDZENIA W POLSCE

\footnotetext{
W artykule zastanawiam się, w jaki sposób ryzyko i zaufanie - rozumiane jako zjawiska społeczne specyficzne dla epoki późnej nowoczesności - odzwierciedlają się w codziennych niepokojach związanych z wyborami jedzeniowymi mieszkańców Polski. W postrzeganiu zagrożeń żywieniowych oraz w znaczeniach przypisywanych różnym źródłom pozyskiwania produktów dostrzegam specyfikę społecznego systemu wartości i jego historyczne uwarunkowania. Na podstawie analizy wypowiedzi siedemdziesięciu rozmówców na temat ich niepokojów jedzeniowych wskazuję na zróżnicowany charakter strategii uwierzytelniających wybory jedzeniowe oraz rodzaje zaufania, jakim obdarza się różnych aktorów społecznych biorących udział w produkcji i dystrybucji żywności. Strategie i charakter zaufania wiążą się w znacznym stopniu z posiadanymi zasobami społecznymi i kulturowymi, dlatego zwracam również uwagę na ich stratyfikacyjny aspekt, a także na ogólny obraz poziomu zaufania do ludzi, instytucji i systemów abstrakcyjnych.
}

Słowa kluczowe: zaufanie, ryzyko, niepokój, jedzenie, codzienność, zakupy 